\title{
Karakterisasi Antosianin Buah Murbei Spesies Morus alba dan Morus cathayana di Indonesia
}

\section{(Anthocyanin Characterization of Morus alba and Morus cathayana in Indonesia)}

\author{
Rehmadanta Sitepu $^{1 *}$, Heryanto ${ }^{2}$, Tatas H.P. Brotosudarmo ${ }^{2}$, Leenawaty Limantara ${ }^{2,3}$ \\ ${ }^{1}$ Program Studi Farmasi Fakultas Sains dan Teknologi Universitas Ma Chung Malang \\ ${ }^{2} \mathrm{Ma}$ Chung Research Center for Photosynthetic Pigmen (MRCPP) \\ Villa Puncak Tidar N-01 Malang, Jawa Timur-Indonesia \\ ${ }^{3}$ Universitas Pembangunan Jaya \\ Jl. Cendrawasih, Kel. Sawah Baru, Kec. Ciputat Tangerang Selatan, Banten, Indonesia.
}

\begin{abstract}
Mulberry fruit has been known to be rich in antioxidants due to its anthocyanin contents. Unfortunately, the utilization of mulberry fruits as a source of antioxidants and therapy is rare in Indonesia. Mulberry plants are only used for feeding domesticated animal or making tea from its leafs. This study aims to characterize anthocyanin of Morus alba and Morus cathayana. Characterization of anthocyanin exctracts from Morus alba and Morus cathayana were performed using solvent $0.1 \%$ hydrochloric acid $(\mathrm{HCl})$ in methanol, and then analized by UV-Vis spectrophotometer and High Performance Liquid Chromatography (HPLC). The results of UV-visible absorption spectra obtained from the crude extract shows that absorption spectra of mulberry extract $M$. cathayana provide higher absorbance \pm 1.3 a.u. compared to absorbance which was obtained from the crude extract of mulberry $M$. alba are on \pm 0.4 a.u. The total anthocyanin obtained from extract of $M$. cathayana, is $40,39 \pm$ $7,64 \mathrm{mg} / \mathrm{g}$ dry weight compared with $M$. alba which has a value $11,57 \pm 3,02 \mathrm{mg} / \mathrm{g}$ dry weight. Results of chromatogram of HPLC using XR-ODS column with elution A was $0.1 \%$ formic acid in acetonitrile and elution B was $0.1 \%$ formic acid in water shows both $M$. cathayana and $M$. alba have two dominant pigments of anthocyanin. However, the intensity of chromatograms obtained from $M$. cathayana is higher than the intensity of chromatograms of $M$. alba. The intensity of chromatogram of $M$. cathayana is $50 \mathrm{mAU}$ on retention time 7.86 minutes and $15 \mathrm{mAU}$ on retention time 8.38 minutes. The intensity of chromatogram of M. alba is $10 \mathrm{mAU}$ on retention time 7.35 minutes and $3 \mathrm{mAU}$ on retention time 7.76 minutes. The two dominant anthocyanins are predicted as cyanidin-3-O-glucoside and cyanidin-3-rutinoside.
\end{abstract}

Key words: Anthocyanin, Morus alba, Morus cathayana

\begin{abstract}
ABSTRAK
Buah murbei kaya antioksidan karena kandungan antosianin yang banyak. Sayangnya, pemanfaatannya sebagai sumber antioksidan di Indonesia masih minim. Pemanfaatan tanaman murbei hanya sebatas daun yang dijadikan pakan ternak dan teh. Penelitian ini bertujuan untuk melakukan karakterisasi antosianin buah murbei spesies Morus alba dan
\end{abstract}


Morus cathayana. Karakterisasi antosianin ekstrak buah murbei Morus cathayana dan Morus alba dilakukan menggunakan pelarut $0,1 \%$ asam klorida $(\mathrm{HCl})$ dalam metanol dan dianalisis menggunakan spektrofotometer UV-tampak dan Kromatografi Cair Kinerja Tinggi (KCKT). Hasil serapan spektra UV-tampak yang diperoleh dari ekstrak kasar menunjukkan spektra serapan ekstrak buah $M$. cathayana memberikan nilai yang lebih tinggi $\pm 1,3$ a.u dibandingkan serapan yang diperoleh dari ekstrak kasar buah $M$. alba dengan serapan $\pm 0,4$ a.u. Nilai total antosianin yang diperoleh dari $M$. cathayana sebanding dengan serapan ekstrak segarnya, yaitu 40,39 \pm 7,64 mg/g berat kering dibandingkan $M$. alba yang memiliki nilai total antosianin $11,57 \pm 3,02 \mathrm{mg} / \mathrm{g}$ berat kering. Hasil kromatogram dari KCKT menggunakan kolom XR-ODS dengan pengelusi A adalah $0,1 \%$ asam formiat dalam asetonitril dan pengelusi $\mathrm{B}$ adalah $0,1 \%$ asam formiat dalam air menunjukkan baik $M$. cathayana maupun $M$. alba memiliki dua pigmen antosianin dominan. Walaupun bergitu, intensitas kromatogram $M$. cathayana lebih tinggi dibandingkan intesitas pada $M$. alba. Nilai intensitas $M$. cathayana adalah 50 mAU untuk waktu tambat 7,86 menit dan 15 mAU untuk waktu tambat 8,38 menit. Nilai intensitas $M$. alba adalah 10 mAU untuk waktu tambat 7,35 menit dan 3 mAU untuk waktu tambat 7,76 menit. Dua antosianin dominan pada $M$. alba dan M. cathayana diprediksi merupakan sianidin-3-O-glukosida dan sianidin-3-O-rutinosida.

\section{Kata kunci: Antosianin, Morus alba, Morus cathayana}

\section{LATAR BELAKANG}

Antosianin merupakan pigmen golongan flavonoid yang larut air berperan penting dalam memberi warna pada tanaman. Pigmen ini tersebar luas pada tanaman termasuk tanaman pangan. Telah banyak studi dilakukan untuk mempelajari efek protektif dari berbagai jenis flavonoid ini di berbagai jenis tanaman dan buah-buahan. Kajian ini mencakup antioksidans antialergi, antiinflamasi, antivirus, antiproliferatif, antimutagenik, antimikro-bial, antikarsinogenik, perlindungan kerusakan kardiovaskular dan alergi, pencegahan diabetes dan peningkatan penglihatan (Zafra-Stone et al., 2007). Aktivitas antioksidan antosianin disebabkan fungsinya sebagai agen pengkelat ion logam dalam beberapa tingkat $\mathrm{pH}$. Antosianin juga diketahui dapat menginduksi enzim-enzim fase II (transferase glutation-S, glukuronosiltransferase difosfat uridin, reduktase quinon, dll.) yang dapat menghambat aktivasi karsinogen yang diaktivasi enzim-enzim fase I, sehingga mencegah kerusakan DNA. Ekstrak yang kaya antosianin juga dapat menghambat $50 \%$ lini sel tumor kolon manusia, mencegah oksidasi LDL secara in vitro yang akan mencegah terjadinya aterosklerosis, dan juga diketahui melindungi LDL dari hidrogen peroksida yang diinduksi stress oksidatif pada kultur sel endotel manusia (Zhao, 2007).

Tumbuhan golongan beri merupakan salah satu sumber antosianin yang potensial

\section{Karakterisasi Antosianin Buah Murbei Spesies Morus alba dan Morus cathayana di Indonesia}

(Rehmadanta Sitepu dkk) 
(Zhao, 2007). Kandungan antosianin pada elderberry diketahui secara signifikan melindungi sel endotelial dari stres oksidatif. Antosianin yang terdapat di dalam blueberry juga diketahui memiliki efek perlindungan terhadap stres oksidatif dan radikal bebas ketika diuji dengan sel darah merah secara in vivo (Zafra-Stone et al., 2007). Sehingga buah beri menjadi penting untuk menggantikan antioksidan sintetik yang selama ini banyak beredar di pasaran (Arfan et al., 2012)

Di Indonesia, referensi mengenai pemanfaatan tanaman beri untuk kesehatan jarang ditemukan. Hal ini sangat berbeda dengan beberapa negara seperti Cina dan Amerika yang produksi murbeinya telah menjadi komoditas ekspor. Indonesia belum memiliki pengetahuan yang luas tentang diversifikasi pemanfaatan tanaman beri. Umumnya tanaman murbei paling banyak dimanfaatkan daunnya untuk pakan pembudidayaan ulat sutera di Indonesia (Singhal et al., 2010).

Ada empat spesies murbei unggul yang dikembangkan di Indonesia, yaitu Morus alba, Morus multicaulis, Morus cathayana, dan Morus nigra. M. nigra merupakan merupakan murbei endemik daerah tropis yang telah diketahui komposisi antosianinnya (Özgen et al., 2009), sedangkan ketiga spesies lainnya merupakan murbei yang berasal dari Cina dan Jepang yang komposisi antosianinnya setelah ditanam di Indonesia belum banyak diteliti (Singhal et al., 2010).

Berdasarkan hal ini akan sangat menarik bila dapat mengetahui seberapa besar kandungan dan profil antosianin dari murbei non endemik daerah tropis di Indonesia.

\section{BAHAN DAN METODE}

Alat dan Bahan

Alat yang digunakan dalam penelitian ini adalah timbangan Sartorius BT2245, blender laboratorium Waring Commercial, spektrofotometer UV-1700 (Shimadzu), moisture tester MOC634 (Shimadzu), kolom shim-pack XR-ODS (100 mm x I.D. $3 \mathrm{~mm}$ ) Shimadzu, autosampler SIL-20 AC XR, pompa LC-20 AD XR, detektor diode array tipe SPD-M20 A.

Bahan yang digunakan dalam penelitian ini adalah murbei spesies $M$. alba yang diambil daerah sekitar Kota Malang sedangkan spesies $M$. cathayana diambil dari Puslitbang Peningkatan Produktivitas Hutan (Pusprohut), Bogor, Provinsi Jawa Barat, metanol (Merck), $\mathrm{HCl}$ (Merck), $\mathrm{KCl}$ (Merck), natrium asetat (E. Merck), akuades. Semua bahan yang digunakan merupakan bahan-bahan untuk analisis.

Preparasi sampel

Sampel buah segar murbei spesies $M$.

\section{Karakterisasi Antosianin Buah Murbei Spesies Morus alba dan Morus cathayana di Indonesia}

(Rehmadanta Sitepu dkk) 
alba dan $M$. cathayana dicuci dengan air mengalir dan dikeringkan dari sisa air cucian. Selanjutnya sampel buah murbei dihaluskan dengan menggunakan blender selama \pm 10 menit. Murbei yang dihaluskan selanjutnya dilakukan pengukuran kadar air.

Penentuan kadar air

Penentuan karakteristik fisik dilakukan dengan menentukan kadar air dengan moisture tester. Masing-masing sampel diletakkan pada alat moisture tester. Alat ini akan bekerja secara otomatis untuk mengukur persentase kadar air masingmasing buah murbei yang dihaluskan. Nilai persentase yang tertera dicatat setelah pengukuran dilakukan. Percobaan ini dilakukan pengulangan sebanyak tiga kali. Nilai persentase kadar air diperoleh dari rerata hasil pengukuran.

\section{Ekstraksi}

Selanjutnya, masing-masing preparat halus buah murbei ditimbang sekitar 0,1 gram, kemudian dimasukkan ke dalam tabung eppendorf $1,5 \mathrm{~mL}$. Pelarut $1 \% \mathrm{HCl}$ dalam metanol ditambahkan sebanyak 1,5 $\mathrm{mL}$ ke dalam tabung eppendorf yang telah terisi sampel murbei (Huang et al., 2011). Kemudian, sampel tersebut dihomogenisasi dengan pelarutnya dengan menggunakan vortex kurang lebih 5 menit. Selanjutnya, sampel tersebut dimaserasi selama 24 jam di dalam freezer pada suhu $-2^{\circ} \mathrm{C}$. Ekstrak yang larut dan residu daging buah dipisahkan dengan sentrifugasi pada 10.000 rpm selama 3 menit. Bagian supernatannya dimasukkan ke dalam labu $5 \mathrm{ml}$ dan ditambahkan pelarut hingga tanda batas.

Labu ukur dihomogenisasi untuk memperoleh campuran ekstrak yang seragam. Selanjutnya, ekstrak tersebut digunakan untuk melakukan pengukuran total antosianin dan karakterisasi antosianin menggunakan kromatografi cair kinerja tinggi (KCKT).

Spektra serapan antosianin ekstrak buah murbei

Sebanyak $100 \mu \mu \quad$ ekstrak dicampurkan dengan $400 \mu \mathrm{L}$ pelarut ekstraksi diukur spektrum serapannya pada interval panjang gelombang $(\lambda)$ 200$900 \mathrm{~nm}$ menggunakan spektrofotometer UV-1700 Pharmaspec (Shimadzu) untuk penetuan jumlah nilai serapan yang ada pada masing-masing sampel.

Penentuan kandungan antosianin

Antosianin total ditentukan dengan menggunakan spektrofotometer. Absorbansi ekstrak kasar antosianin pada $\mathrm{pH}$ 1,0 dan $\mathrm{pH} 4,5$ diukur pada $\lambda 510 \mathrm{~nm}$ dan $700 \mathrm{~nm}$.

\section{Karakterisasi Antosianin Buah Murbei Spesies Morus alba dan Morus cathayana di Indonesia}




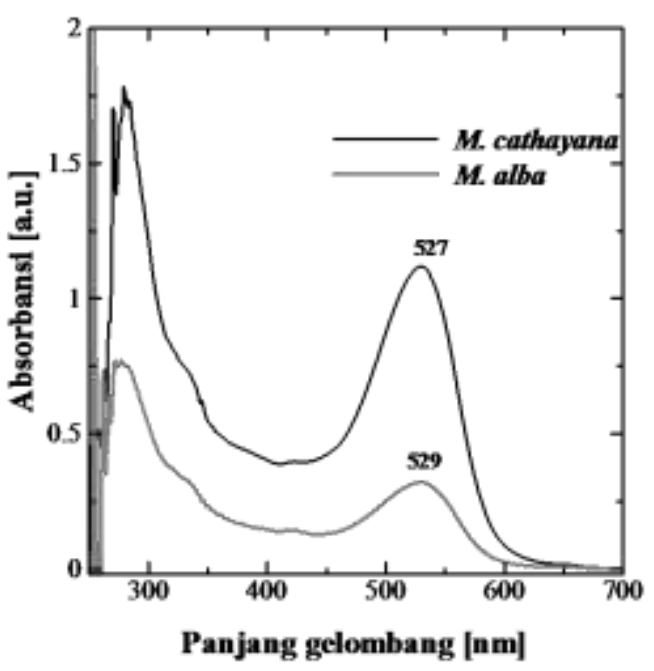

Gambar 1 Perbandingan spektra UV-tampak ekstrak kasar M. alba dan M. cathayana

Absorbansi yang diperoleh dari masing-masing $\lambda$ pada $\mathrm{pH} 1,0$ dan $\mathrm{pH} 4,5$ dimasukkan ke dalam rumus seperti yang dijelaskan oleh Aramwit et al., 2010 :

$A=\left[\left(A_{510}-A_{700}\right)\right]_{p H ~ 1,0}-\left[\left(A_{510}-A_{700}\right)\right]_{p H} 4,5$

Dimana $\mathrm{A}=$ absorbansi total antosianin; $\mathrm{A} 510=$ absorbansi yang diukur pada $\lambda 510$ $\mathrm{nm} ; \mathrm{A} 700=$ absorbansi yang diukur pada $\lambda$ $700 \mathrm{~nm}$.

Kandungan antosianin total dihitung berdasarkan Gardana et al., 2014 dengan rumus :

$$
C=\frac{A \times M W \times D F \times V}{\varepsilon \times L \times W_{t}} \times 1000
$$

dimana, $\mathrm{C}=$ kandungan antosianin $\left(\mathrm{g} \mathrm{kg}^{-1}\right)$ $\varepsilon=$ koefisien ekstingsi sianidin 3-glukosida (26.900 $\left.\mathrm{L} \mathrm{cm}^{-1} \mathrm{~mol}^{-1}\right) ; \mathrm{L}=$ lebar kuvet $(1$ $\mathrm{cm}) ; \mathrm{MW}=$ berat molekul sianida 3glukosida $\left(0,445 \mathrm{~kg} \mathrm{~mol}^{-1}\right) ; \mathrm{DF}=$ faktor pengenceran; $\mathrm{W}_{\mathrm{t}}=$ berat sampel $(\mathrm{g})$ (Gardana et al., 2014).

Penentuan jenis antosianin dengan KCKT

Ekstrak antosianin yang berasal dari M. alba dan $M$. cathayana ditentukan komponen penyusunnya dengan menggunakan KCKT. Metode KCKT yang digunakan adalah metode KCKT yang telah dimodifikasi dari metode Shimadzu (Lopes-Da-Silva et al., 2002). Kolom XRODS digunakan sebagai fase diam, sedangakan fase gerak $0,1 \%$ asam formiat dalam akuades (A) dan $0,1 \%$ asam formiat dalam asetonitril (B) dengan laju alir 0,5 $\mathrm{ml} / \mathrm{menit}$.

\section{Karakterisasi Antosianin Buah Murbei Spesies Morus alba dan Morus cathayana di Indonesia}




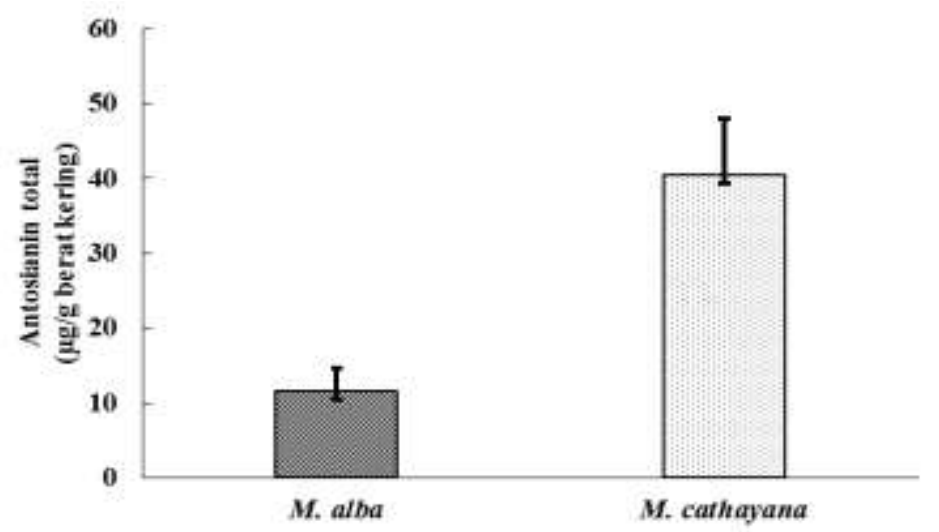

Gambar 2 Perbandingan total antosianin ekstrak M. alba dan M. cathayana

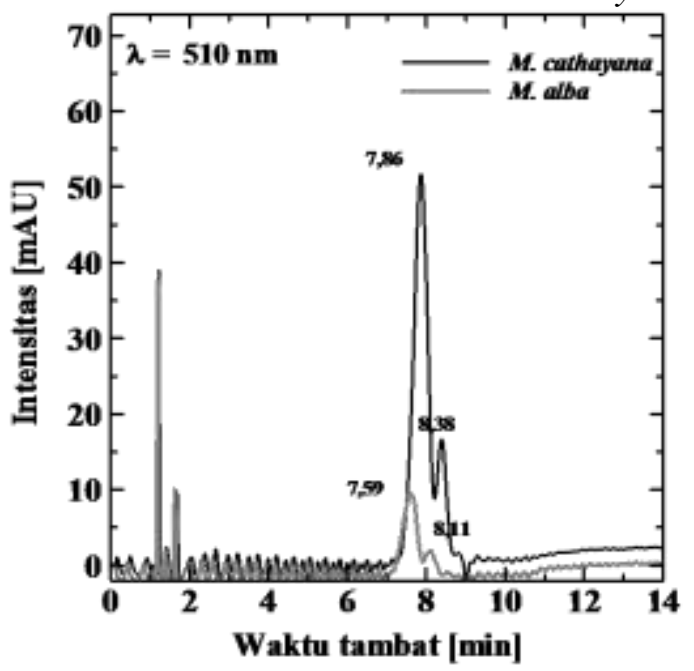

Gambar 3 Kromatogram KCKT M. alba dan M. cathayana

Kondisi eluen pada 0,01 menit 5\% B; 15 menit $25 \%$ B; 15,01 menit $95 \%$ B; 20 menit $95 \% \mathrm{~B}$; dan pada 25 menit $5 \%$ B. Antosianin dideteksi pada $\lambda 510 \mathrm{~nm}$. Selanjutnya hasil yang diperoleh dari analisis KCKT digunakan untuk menentukan komponen antosianin berdasarkan waktu tambat, spektra serapan, dan selain itu, kuantitas setiap antosianin ditentukan berdasarkan luas puncak masing-masing komponen.

\section{HASIL}

Penentuan kadar air pada buah murbei M. alba dan $M$. cathayana diperoleh dengan memvariasikan massa buah murbei yang diletakkan pada moisture tester. Hasil pegukuran menunjukkan kadar air M. alba adalah $86,02 \pm 1,61 \%$ sedangkan M. cathayana adalah $84,68 \pm 4,10 \%$.

Pola spektral ekstrak antosianin buah segar M. alba dan M. cathayana diukur terlebih dahulu sebelum menentukan nilai antosianin total dengan menggunakan buffer $\mathrm{pH}$ 4,5 dan $\mathrm{pH} 1$.

\section{Karakterisasi Antosianin Buah Murbei Spesies Morus alba dan Morus cathayana di Indonesia}


Hasil pengukuran dengan menggunakan spektroskopi UV-tampak menunjukkan nilai serapan absorbansi ekstrak $M$. cathayana yang lebih tinggi dari $M$. alba pada panjang gelombang serapan maksimum $\left(\lambda_{\text {maks }}\right)$. Hasil yang disajikan pada Gambar 1 dapat menunjukkan nilai absorbansi ekstrak M. cathayana pada $\lambda_{\text {maks }} 527 \mathrm{~nm}$ adalah 1,3 a.u. dan absorbansi $M$. alba pada $\lambda_{\text {maks }} 529 \mathrm{~nm}$ adalah 0,4 a.u.

Nilai total antosianin diperoleh dari pengukuran absorbansi ekstrak kasar $M$. alba dan M. cathayana buffer $\mathrm{pH}$ 4,5 dan $\mathrm{pH} 1,0$ yang diukur pada $\lambda 510 \mathrm{~nm}$ dan $\lambda$ $700 \mathrm{~nm}$. Nilai total antosianin dihitung berdasarkan nilai absorbansi yang diperoleh dari masing-masing $\lambda$ dengan menggunakan rumus (1).

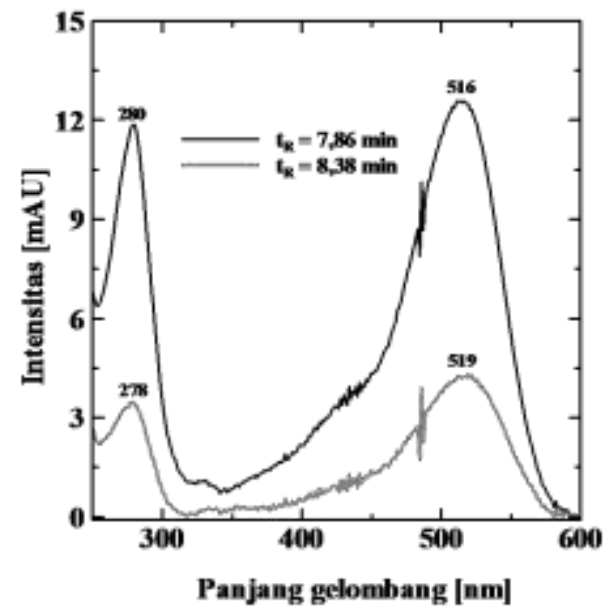

Gambar 4 Pergeseran serapan maksimum antosianin pada ekstrak M. cathayana

Tabel 1 Tabel luas area dominan pada $\lambda 510 \mathrm{~nm}$ hasil KCKT M. alba dan M. cathayana Catatan : a)Wu et al., 2011; b) Zhang et al., 2011

\begin{tabular}{clccccc}
\hline \multirow{2}{*}{$\begin{array}{c}\text { No. } \\
\text { Puncak }\end{array}$} & Sampel & \multicolumn{2}{c}{ Penelitian ini } & \multicolumn{2}{c}{$\begin{array}{c}\text { Pustaka } \\
\text { acuan }\end{array}$} & Hipotesis \\
\cline { 2 - 5 } & & $\begin{array}{c}\text { Waktu tambat } \\
(\mathbf{m e n i t})\end{array}$ & $\begin{array}{c}\lambda_{\text {maks }} \\
(\mathbf{n m})\end{array}$ & $\begin{array}{c}\text { Waktu } \\
\text { tambat }\end{array}$ & $\begin{array}{c}\lambda_{\text {maks }} \\
(\mathbf{n m})\end{array}$ & \\
\hline \multirow{2}{*}{1} & M. alba & 7,35 & 514 & $8,90^{\text {a) }} ;$ & $518 ;$ & sianidin-3-O-glukosida \\
\cline { 2 - 5 } & M. cathayana & 7,86 & 516 & $8,00^{\text {b) }}$ & 516 & \\
\hline \multirow{2}{*}{2} & M. alba & 7,76 & 517 & $10,32^{\text {a) }} ;$ & $519 ;$ & sianidin-3-O-rutinosida \\
\cline { 2 - 5 } & M. cathayana & 8,38 & 519 & $8,38^{\text {b) }}$ & 518 & \\
\hline
\end{tabular}

Hasil pengukuran yang disajikan pada Gambar 2 menunjukkan bahwa nilai antosianin total yang berasal dari ekstrak kasar antosianin $M$. cathayana lebih tinggi dengan nilai $40,39 \pm 7,64 \mu \mathrm{g} / \mathrm{g}$ berat kering atau berkisar 145,23 $\mathrm{mg} / \mathrm{l}$ dibandingkan nilai antosianin total pada M. alba dengan nilai $11,57 \pm 3,02 \mu \mathrm{g} / \mathrm{g}$

\section{Karakterisasi Antosianin Buah Murbei Spesies Morus alba dan Morus cathayana di Indonesia}


berat kering atau berkisar $31,72 \mathrm{mg} / \mathrm{l}$.

Hasil kromatogram KCKT menggunakan kolom XR-ODS dengan pengelusi $0,1 \%$ asam formiat dalam asetonitril sebagai pelarut A dan $0,1 \%$ asam formiat sebagai pelarut $B$ menunjukkan adanya dua puncak yang terdeteksi pada $\lambda 510 \mathrm{~nm}$ pada waktu tambat yang berbeda. Waktu tambat kedua kromatogram ini pada 7,86 menit dan 8,38 menit untuk $M$. cathyana dan 7,35 serta 7,76 menit pada M. alba (Gambar 3).

Intensitas kromatogram yang dihasilkan juga sangat berbeda untuk masing-masing sampel. Gambar 3 menunjukkan intesitas kromatogram yang diperoleh dari M. cathayana $(7,86$ menit $=50 \mathrm{mAU} ; 8,38$ menit $=15 \mathrm{mAU}$ ) lebih tinggi dibandingkan dari intensitas yang dihasilkan dari M. alba $(7,35$ menit $=10$ mAU; 7,76 menit $=3$ mAU). Hal ini juga terkait dengan jumlah total antosianin yang terkandung jauh lebih banyak pada $M$. cathayana dibandingkan dengan $M$. alba.

Gambar 4 menunjukkan pergeseran $\lambda_{\text {maks }}$ untuk puncak antosianin 1 dan antosianin 2 pada M. cathayana. Pada waktu tambat 7,86 menit menunjukkan serapan maksimum pada $\lambda 516 \mathrm{~nm}$ dan pada waktu tambat 8,38 menit menunjukkan serapan pada $\lambda 519 \mathrm{~nm}$. Hasil penelitian ini menunjukkan terdapatnya dua antosianin dominan yang diperkirakan merupakan jenis antosianin yang sama untuk masing-masing spesies murbei. Berdasarkan hasil penelusuran pustaka yang dipertimbangkan melalui kedekatan $\lambda_{\text {maks }}$ dan waktu retensi, maka antosianin yang terdapat pada kedua spesies murbei diperkirakan sianidin-3O-glukosida dan sianidin-3-O-rutinosida (Wu et al., 2011). Hal ini seperti yang tertera pada Tabel 1.

Selanjutnya masing-masing ekstrak murbei diplot terhadap luas puncak yang diperoleh sebagai gambaran kuantitatif perbandingan jumlah masing-masing antosianin pada sampel murbei. Gambar 5 memberikan informasi mengenai dua puncak antosianin dominan yang terdapat pada masing-masing murbei. Baik sianidin-3-O-glukosida maupun sianidin3-O-rutinosida lebih dominan pada ekstrak murbei $M$. cathayana dengan luas puncak mencapai 400 unit (sianidin-3-Oglukosida) dan 100 unit (sianidin-3-Orutinosida). Dari Gambar 5 juga diperoleh informasi bahwa pigmen yang paling dominan pada masing-masing sampel murbei adalah sianidin-3-O-glukosida.

\section{Karakterisasi Antosianin Buah Murbei Spesies Morus alba dan Morus cathayana di Indonesia}

(Rehmadanta Sitepu dkk) 


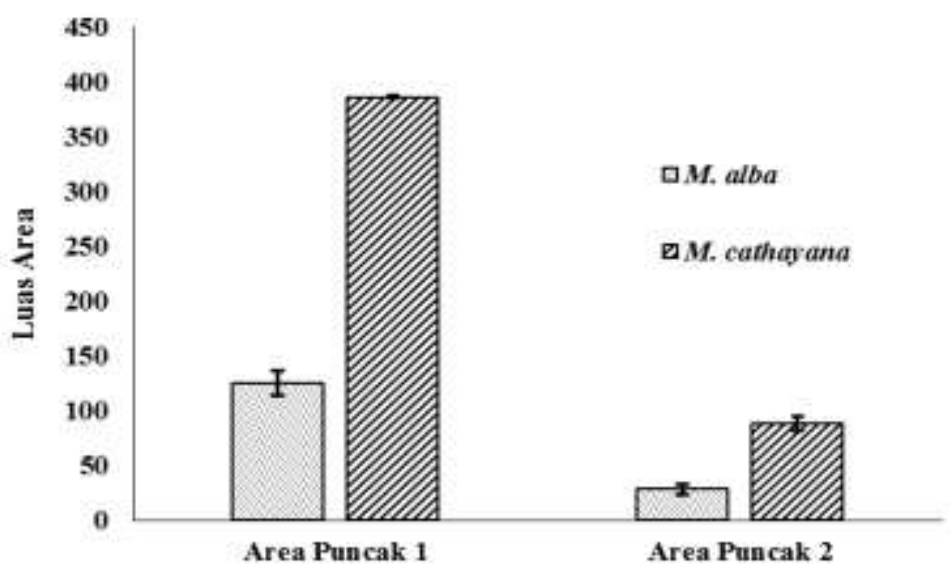

Gambar 5 Perbandingan luas puncak dari masing-masing waktu tambat M. alba dan M. cathayana

\section{PEMBAHASAN}

Ekstraksi antosianin pada buah murbei $M$. alba dan $M$. cathayana yang dilakukan menggunakan pelarut $1 \% \mathrm{HCl}$ dalam metanol (Ge \& Ma, 2013) dapat memberikan interpretasi yang baik dalam membandingkan kandungan antosianin pada masingmasing spesies murbei meskipun pada penggunaannya metode ini tidak dapat mengekstraksi seluruh pigmen yang ada pada daging buah masing-masing spesies. Peruntukan untuk dapat mengekstraksi seluruh pigmen total diperlukan konsentrasi asam yang lebih tinggi atau penambahan beberapa jenis asam (Du et al., 2008). Hassimotto et al., 2007 melakukan ekstraksi dengan komposisi pelarut metanol : asam formiat $(9: 1, \mathrm{v} / \mathrm{v})$ atau dengan pelarut metanol, air, dan asam asetat (70:30:5, v/v) dapat mengekstrak seluruh pigmen antosianin.

Dari hasil yang diperoleh menggunakan metode ini, baik dari nilai absorbansi pada $\lambda_{\text {maks }}$ dari spektra serapan ekstrak kasar (Gambar 1) maupun nilai total antosianin (Gambar 2) yang diperoleh berdasarkan hasil analisis menggunakan spektrofotometer UVtampak menunjukkan suatu korelasi yang mengintepretasikan bahwa kandungan antosianin pada $M$. cathayana lebih banyak dibandingkan kandungan antosianin yang terdapat pada M. alba.

Penentuan nilai absorbansi pada $\lambda_{\text {maks }}$ dari spektra serapan ekstrak kasar tanpa perlakuan dalam $\mathrm{pH}$ tertentu perlu dilakukan mengingat ketidakstabilan beberapa komponen antosianin. Keberadaan $\mathrm{pH}$ juga sangat mempengaruhi kestabilan antosianin. Antosianin akan berubah

\section{Karakterisasi Antosianin Buah Murbei Spesies Morus alba dan Morus cathayana di Indonesia}

(Rehmadanta Sitepu dkk) 
ke beberapa bentuk dalam $\mathrm{pH}$ tertentu. Pada $\mathrm{pH}$ 1, kation flavilium yang berwarna merah dan ungu merupakan spesies dominan. Pada $\mathrm{pH}$ antara 2-4 membentuk spesies dominan kuinoidal yang berwarna biru. Pada pH 4-6 akan membentuk 2 senyawa tidak berwarna, karbinol pseudobase dan kalkon (CastañedaOvando et al., 2009). Atas dasar terbentuknya senyawa-senyawa berwarna pada $\mathrm{pH}$ tertentu ini yang digunakan sebagai acuan dasar untuk menentukan total antosianin berdasarkan rumus (1). Liu et al., 2004 pada penelitiannnya menyatakan bahwa rentang kandungan antosianin pada buah murbei berkisar antara $147-2.725 \mathrm{mg} / \mathrm{l}$, berdasarkan hal ini, maka hanya $M$. cathayana masuk dalam kriteria ini yang memiliki antosianin total berkisar pada $145,23 \mathrm{mg} / \mathrm{l}$.

Hasil analisis menggunakan spektrofotometer diperkuat dengan data kromatogram KCKT yang menunjukkan adanya dua puncak dari masing-masing ekstrak murbei $M$. alba dan $M$. cathayana. Nilai intensitas dua puncak pada kromatogram KCKT ini berbeda antara spesies satu dengan yang lain. Nilai intensitas lebih tinggi ditunjukkan oleh $M$. cathayana dengan nilai intensitas mencapai 50 mAU pada waktu tambat 7,86 menit dan intensitas mencapai $15 \mathrm{mAU}$ untuk waktu tambat 8,38 menit (Gambar 3).
Spektra serapan 2 jenis antosianin yang dapat dipisahkan menggunakan KCKT (Gambar 4) pada masingmasing sampel menunjukkan adanya pergeseran $\lambda_{\text {maks }}$ sebesar 1-10 $\mathrm{nm}$. Hal ini dapat dipengaruhi oleh jenis antosianin yang terkandung dalam sampel. Misalnya $\lambda_{\text {maks }}$ sianidin-3-Oglukosida pada $\lambda 518 \mathrm{~nm}$, sedangkan delfinidin-3-rutinosida terdeteksi pada $\lambda_{\text {maks }} 526 \mathrm{~nm}$ (Wu et al., 2011).

Nilai $\lambda_{\text {maks }}$ yang diperoleh untuk setiap puncak ditunjukkan pada Tabel 1 selanjutanya dibandingkan dengan pustaka yang ada sehingga dapat memberikan informasi mengenai jenis antosianin yang ada pada masing-masing sampel murbei. Pustaka acuan yang ditampilkan adalah pustaka dengan kondisi KCKT yang hampir sama dengan penelitian ini, yaitu menggunakan kolom C-18 $(150 \times 4,60 \mathrm{~mm}, 5 \mu \mathrm{m})$ dengan fase gerak $1 \%$ asam triflouoroasetat dalam air dan asetonitril. Namun kondisi eluen yang digunakan pada masingmasing pustaka berbeda-beda. Panjang kolom C-18 yang digunakan pada penelitian ini $100 \mathrm{~mm}$, lebih pendek dari pustaka acuan, sehingga menjadi alasan waktu retensi yang diperoleh lebih pendek juga. Kondisi Penelusuran berdasarkan pustaka ini 
perlu dipastikan kembali secara eksperimental untuk memastikan kandungan yang ada. Untuk tujuan ini maka diperlukan penentuan jenis antosianin yang terkandung dengan menggunakan Spektroskopi Massa (SM) dan Resonansi Magnet Inti (RMI) (Castañeda-Ovando et al., 2009). Data yang diperoleh dari Spektroskopi Massa (data akan ditampilkan pada publikasi selanjutnya) menunjukkan bahwa puncak 1 pada kedua spesies murbei dengan waktu tambat 7,35 dan 7,86 menit memberikan nilai $[\mathrm{M}]^{+}=449$ yang merupakan berat molekul sianidin-3-O-glukosida, (Qin et al., 2010) sedangkan puncak 2 baik dengan waktu tambat 7,76 dan 8,38 menit memberikan nilai $[\mathrm{M}]^{+}=595$ yang merupakan berat molekul sianidin-3-rutinosida. (Zafra-Stone et al., 2007)

Sianidin-3-O-glukosida dan sianidin-3-rutinosida merupakan jenis antosianin yang paling dominan pada buah murbei. Secara keseluruhan berdasarkan pustaka, 64\% antosianin buah murbei merupakan sianidin-3O-glukosida dan $35 \%$ adalah sianidin-3-rutinosida (Ştefănuţ et al., 2011). Hasil KCKT seperti Gambar 5 menunjukkan adanya 2 antosianin dominan yang terkandung pada masing-masing murbei. Perbandingan intensitas dari dua puncak dominan ini berkisar $4: 1$ atau $5: 1$. Dari hasil penelusuran pustaka tersebut, diprediksi komponen antosianin dominan pada dua spesies murbei yaitu sianidin-3-O-glukosida dan sianidin3-rutinosida (Qin et. al., 2010). Walaupun pada penelitian ini $\lambda_{\text {maks }}$ M. alba sedikit bergeser dari pustaka acuan, namun dengan kolom XRODS, yang diharapakan mucul pertama kali adalah komponenkomponen yang polar termasuk sianidin-3-O-glukosida dan sianidin3-rutinosida. Pergeseran $\lambda_{\text {maks }}$ juga dapat disebabkan karena elusi pelarut bergradien dimana pada penelitian ini menggunakan 5\% pelarut $\mathrm{B}$ pada 0,01 menit hingga $25 \%$ pelarut $\mathrm{B}$ pada saat 15 menit. Pola spektra masing-masing puncak pada penelitian ini juga menyerupai pola spektra dari pustaka acuan (Qin et al., 2010).

Hasil ini dapat dijadikan sebagai acuan dalam pemilihan jenis buah murbei yang diharapkan dapat digunakan sehingga meningkatkan nilai ekonomis murbei. Beberapa penelitian terbaru menunjukkan bahwa sianidin-3-O-glukosida dan

\section{Karakterisasi Antosianin Buah Murbei Spesies Morus alba dan Morus cathayana di Indonesia}

(Rehmadanta Sitepu dkk) 
sianidin-3-rutinosida memiliki efek dalam menghambat migrasi dan invasi sel kanker paru-paru manusia (Chen et al., 2006). Penelitian terbaru yang dilakukan di Indonesia menunjukkan adanya efek antibakteri buah murbei terhadap bakteri Staphylococcus aureus dan Shigella dysenteriae (Hastuti et al., 2012). Penelitian untuk menentukan kualitas kandungan antosianin buah murbei di beberapa daerah di Indonesi juga diperlukan untuk melihat potensi daerah yang dapat memberikan jumlah kandungan antioksidan yang lebih banyak. Penelitian dengan tujuan ini hanya dilakukan di Makassar untuk menentukan determinasi $M$. alba di beberapa lokasi di Makassar dengan menggunakan spektroskopi Fourier Transform-Infra Red (FT-IR) (Syahruni et al., 2016). Dari beberapa referensi ini dapat disimpulkan bahwa pemanfaatan dan penelitian murbei di Indonesia dalam lingkup farmasi masih terbatas, sehingga diperlukan penelitian yang lebih komprehensif untuk mengali potensi farmakologi buah ini sehingga dapat meningkatkan pemanfaatannya di bidang kesehatan.

\section{UCAPAN TERIMA KASIH}

Terima kasih kepada Universitas Ma Chung yang memberikan dana untuk penelitian ini dalam bentuk skema Penelitian Dosen Pemula Universitas Ma Chung. Terima kasih kepada Puslitbang Peningkatan Produktivitas Hutan (Pusprohut), Bogor, Provinsi Jawa Barat yang memberikan sampel buah murbei.. Terima kasih kepada Ma Chung Research Center for Photosynthetic Pigmen (MRCPP) dimana penelitian ini dilakukan.

\section{DAFTAR PUSTAKA}

Aramwit, P., Bang, N. \& Srichana, T., 2010. The Properties and Stability Of Anthocyanins In Mulberry Fruits. Food Research International, 43(4), pp.1093-1097. Available at: http://dx.doi.org/10.1016/j.foodres.20 10.01.022.

Arfan, M. et al., 2012. Antioxidant Activity Of Mulberry Fruit Extracts. International Journal of Molecular Sciences, 13, pp.2472-2480.

Castañeda-Ovando, A. et al., 2009. Chemical Studies Of Anthocyanins: A Review. Food Chemistry, 113(4), pp.859-871. Available at: http://dx.doi.org/10.1016/j.foodchem. 2008.09.001.

Chen, P.N. et al., 2006. Mulberry Anthocyanins, Cyanidin 3-Rutinoside And Cyanidin 3-Glucoside, Exhibited An Inhibitory Effect On The Migration And Invasion Of A Human Lung Cancer Cell Line. Cancer Letters, 235(2), pp.248-259.

\section{Karakterisasi Antosianin Buah Murbei Spesies Morus alba dan Morus cathayana di Indonesia}


Du, Q., Zheng, J. \& Xu, Y., 2008. Composition Of Anthocyanins In Mulberry And Their Antioxidant Activity. Journal of Food Composition and Analysis, 21(5), pp.390-395.

Gardana, C. et al., 2014. Bilberry Adulteration: Identification and Chemical Profiling of Anthocyanins by Different Analytical Methods. Journal of Agricultural and Food Chemistry, 62(45), pp.10998-11004.

Ge, Q. \& Ma, X., 2013. Composition And Antioxidant Activity Of Anthocyanins Isolated From Yunnan Edible Rose (An ning). Food Science and Human Wellness, 2(2), pp.68-74. Available at: http://www.sciencedirect.com/science /article/pii/S2213453013000244

[Accessed January 14, 2015].

Hassimotto, N.M. a., Genovese, M.I. \& Lajolo, F.M., 2007. Identification and Characterisation of Anthocyanins from Wild Mulberry (Morus Nigra L.) Growing in Brazil. Food Science and Technology International, 13, pp.17-25.

Hastuti, U.S. et al., 2012. DAYA Antibakteri Ekstrak Daun Dan Buah Murbei (Morus alba L.) Terhadap Staphylococcus aureus dan Shigella dysenteriae. Prosiding Seminar Nasional BiologiSeminar Nasional IX Pendidikan Biologi FKIP UNS, 9(1), pp.529-534.

Huang, H.P. et al., 2011. AnthocyaninRich Mulberry Extract Inhibit The Gastric Cancer Cell Growth In Vitro And Xenograft Mice By Inducing Signals of P38/P53 And C-Jun. Food Chemistry, 129(4), pp.1703-1709. Available at: http://dx.doi.org/10.1016/j.foodchem. 2011.06.035.

Liu, X. et al., 2004. Quantification and Purification of Mulberry Anthocyanins with Macroporous Resins. Journal of biomedicine \& biotechnology, 5(5), pp.326-331. Available at: http://www.pubmedcentral.nih.gov/ar ticlerender.fcgi?artid=1082888\&tool $=$ pmcentrez\&rendertype $=$ abstract.

Lopes-Da-Silva, F. et al., 2002. Identification of Anthocyanin Pigments In Strawberry (cv Camarosa) by LC Using DAD and ESI-MS Detection. European Food Research and Technology, 214, pp.248-253.

Özgen, M., Serçe, S. \& Kaya, C., 2009. Phytochemical and Antioxidant Properties of Anthocyanin-Rich Morus nigra and Morus rubra Fruits. Scientia Horticulturae, 119(3), pp.275-279.

Qin, C. et al., 2010. Analysis and Characterisation of Anthocyanins In Mulberry Fruit. Czech Journal of Food Sciences, 28(2), pp.117-126.

Singhal, B.K. et al., 2010. Approaches to Industrial Exploitation of Mulberry (Mulberry sp.) Fruits. J. Fruit Ornamental Plant Res., 18(1), pp.8399.

Ştefănuţ, M.N. et al., 2011. Anthocyanins HPLC-DAD and MS Characterization, Total Phenolics, and Antioxidant Activity of Some Berries Extracts. Analytical Letters, 44(18), pp.2843-2855. Available at: http://www.tandfonline.com/doi/abs/1 0.1080/00032719.2011.582550.

Umar, A., Syahruni, R., Burhan, A., Maryam, F., \& Masero, L. R. (2016). Determinasi Dan Analisis Finger Print Tanaman Murbei (Morus alba Lour) Sebagai Bahan Baku Obat Tradisional Dengan Metode Spektroskopi FT-IR dan Kemometrik. Pharmacon, 5(1), 78-90.

Wu, X. et al., 2011. Aqueous Two-Phase Extraction, Identification and Antioxidant Activity of Anthocyanins From Mulberry (Morus atropurpurea Roxb.). Food Chemistry, 129(2), pp.443-453. Available at: 
http://dx.doi.org/10.1016/j.foodchem. 2011.04.097.

Zafra-Stone shirley, Yasmin T, Bagchi M, Chatterjee A, Vinson JA, Bagchi D. Anthocyanins--occurrence, chemistry extraction and. Mol Nutr Food Res. 2007;51:675-683.

doi:10.3390/ijms13022472.

Zhang, W. et al., 2011. Separation and Character Analysis of Anthocyanins From Mulberry (Morus alba L.) Pomace. Czech Journal of Food Sciences, 29(3), pp.268-276.

Zhao, Y. (Ed.), 2007. Berry Fruit: ValueAdded Products For Health Promotion. CRC Press, Boca Raton. 